\title{
Growth response of pigeon pea (Cajanus cajan L. Millsp) on saline and alfisol soils
}

\author{
M. Soedarjo* \\ Indonesian Legume and Tuber Crops Research Institute, P.O. Box 66, Malang, Indonesia 65101
}

\begin{abstract}
As an archipelago country, Indonesia is surrounded by abundant saline soils which could be potential for growing food crops. The research work was conducted to study the growth responses of some pigeon pea genotypes on saline soils. The genotypes of Pigeon pea (LG Kidul, Mega, 90024, 91043 and 94028), as treatment, were grown on Alfisol soil (nonsaline) and on saline soil. The experiment was carried out using completely randomized design and replicated three times. All data observed were analyzed by employing standard deviation from 3 replicates. The results of present research work revealed a significant growth retardation of pigeon pea when grown on saline soil. All growth parameters, plant height, plant diameter, root dry weight, and shoot dry weight were significantly lower on saline soil than on Alfisol soil. High concentration of $\mathrm{Na}^{+}$was observed in roots, shoots and leaves of pigeon pea indicating growth retardation and toxicity symptoms of pigeon pea on saline soil was due to $\mathrm{Na}^{+}$.
\end{abstract}

\section{Introduction}

Soluble salts, such as sodium, calcium and magnesium, dissolved in soil water contributed to saline environment of soil. Indonesia is expected to harbor a huge amount of land situated with saline condition as a consequent of being an archipelago country where the islands are surrounded by sea. The sea water would intrude further to the land off the seashore and cause salt accumulation, especially sodium, in water near the soil surface and establish saline environment.

Saline soils were reported to be unfavorable for some plants like soybean, peanut and rice, hampering the growth of these plants and cause the harvest failed [1, 2, 3, 4]. Porang (Amorphophallau muelleri Blume) was also found to be susceptible to saline environment [5]. Application of agronomic technology and the use of particular genotypes of susceptible crops, did not significantly increase yield up to the degree beneficial to the farmers $[2,4]$. Our field observation, however, Leucaena, banana, grasses, maize and coconut plants along the seashore of East Java showed normal growth, without saline toxicity symptoms. Some rice varieties were found to be tolerant to saline environment [6]. This observation and the previous research findings suggest the presence of genotypes of some plant species responsible for tolerance to saline environment.

Pigeon pea, not like in India, is not commonly consumed as one of important food sources for Indonesian people. The young pod of pigeon pea was consumed by steaming. However,

* Corresponding author: $\underline{\text { muchdar.soedarjo62@gmail.com }}$ 
seeds of pigeon pea is potential for food diversification [7]. Pigeon pea belonging to the same family to soybean is generally grown as a vegetable or processed to products, like tempe, fermented pigeon pea, or some cakes $[7,8]$. As potential food crops for future, pigeon pea has potential to be cultivated in unfavorable soil, such as dry soils, acid soil and saline soils. These soils are abundant in Indonesia. However, studies on the response pigeon pean growth in saline soils remain limited. The present study was aimed to evaluate the growth response of pigeon pea in saline soils.

\section{Materials and methods}

\subsection{Soil and plant preparation}

Saline and Alfisol (non-saline) soils were obtained from Probolinggo regency, East Java, Indonesia. The soils were taken from the topsoil layer $(20 \mathrm{~cm} \mathrm{dept})$. Soil samples were analyzed at the Soil and Plant Chemical Laboratory of Indonesian Legume and Tuber Crops Research Institute (ILeTRI) (ISO/IEC 17025-2017). After air drying, the soils were crushed to pass through $0.5 \mathrm{~mm}$ sieve. Then, $3 \mathrm{~kg}$ of the soil was put into a polyethylene bag $(12.5$ $\mathrm{cm} \times 25 \mathrm{~cm})$. The soil was watered to maximum water holding capacity and was kept overnight to drain out the excessive water to achieve water field capacity.

Five pigeon pea varieties (L.G. Kidul, Mega, 90024, 91043 and 94028) were used in the study. Good quality seeds were obtained from the germplasm section of ILeTRI. Three pigeon pea seeds of each variety were sown both on saline soil and Alfisol soil (non-saline). Thinning was done to keep one healthy seedling per bag at 5 days after sowing. NPK fertilizer (16:16:16) at the rate of $200 \mathrm{~kg} / \mathrm{ha}$ was applied at 5 days after sowing. The population of pigeon pea is approximately 250000 plants/ha when the spacing of $40 \mathrm{~cm} \times 10 \mathrm{~cm}$ is used. Thus, NPK fertilizer of $0.8 \mathrm{~g}$ was applied in each plant/bag. During the experiment, the soil was watered in every other day to maintain water field capacity. Weeds were pulled out to prevent pigeon pea from nutrient and water competition. whenever necessary, spraying of insecticide and fungicide was undertaken to prevent plants from damages caused by insects and diseases.

\subsection{Experimental design}

The experiment was done in the glass house of ILeTRI from June to August 2019. Th experiment used five pigeon pea varieties (L.G. Kidul, Mega, 90024, 91043 and 94028) as treatment. Each treatment was arranged in completely randomized design and was replicated three times. Plant nutrient analysis, e.g., N, P, K and Na, was done at Soil and Plant Laboratory of ILeTRI (ISO/IEC 17025-2017). Plant height, stem diameter, dry weight of root and dry weight of shoot were measured to evaluate the effect of salinity. Plant height was measured from the soil surface up to the tip of the shoot. Stem diameter was measured at the shoot right on the soil surface. Roots and shoots and leaves were oven-dried and weighed. Standard Deviation from three replicates was employed to analyze all data of each observation. 


\section{Results and discussion}

\subsection{Soil chemical properties}

Table 1 presented chemical characteristics differences between saline and Alfisol soils. Saline soil was characterized by higher $\mathrm{pH}, \mathrm{Ca}, \mathrm{Na}$ and electrical conductivity than Alfisol soil. Higher $\mathrm{Ca}$ and $\mathrm{Na}$ contributed significantly to salinity as measured with electrical conductivity (EC). Sodium as Cation Exchange Capacity and EC of saline soil was doubled compared to $\mathrm{Na}$ and EC of Alfisol soil. High $\mathrm{Na}$ and EC of saline soil in East Java was also reported by the previous investigators $[1,5]$. Therefore, high $\mathrm{Na}$ and $\mathrm{EC}$ are the main characteristic of saline soil, in addition to high $\mathrm{pH}$ and high content of another cation such as Ca.

Table 1. Soil chemical properties of saline and Alfisol soils.

\begin{tabular}{lcc}
\hline Chemical properties & Saline soil & Alfisol soil (non-saline) \\
\hline $\mathrm{pH} \mathrm{H} \mathrm{H}_{2} \mathrm{O}(1: 5)$ & 8.30 & 6.20 \\
$\mathrm{~N}-\mathrm{Total}(\mathrm{Kjedahl})(\%)$ & 0.01 & 0.05 \\
$\mathrm{P}_{2} \mathrm{O}_{5} \mathrm{Olsen}(\mathrm{ppm})$ & 147 & 96.50 \\
$\mathrm{~K}-\mathrm{NH}_{4} \mathrm{OAc} . \mathrm{pH} 7.0$ & 0.39 & 0.88 \\
$\left(\mathrm{Cmol}^{+} / \mathrm{kg}\right)$ & & \\
$\mathrm{C}-\mathrm{Org}-\mathrm{Walkley} \mathrm{\& Black}$ & 0.76 & 1.15 \\
$(\%)$ & 1.05 & 0.50 \\
$\mathrm{Na}\left(\mathrm{Cmol}^{+} / \mathrm{kg}\right)$ & 10.34 & 1.05 \\
$\mathrm{Ca}\left(\mathrm{Cmol}^{+} / \mathrm{kg}\right)$ & 3.88 & 3.94 \\
$\mathrm{Mg}\left(\mathrm{Cmol}^{+} / \mathrm{kg}\right)$ & 34.30 & 17.14 \\
Electric Coductivity & & \\
$(\mathrm{EC})(\mu \mathrm{S} / \mathrm{cm})$ &
\end{tabular}




\subsection{Effect of salinity on plant nutrient}
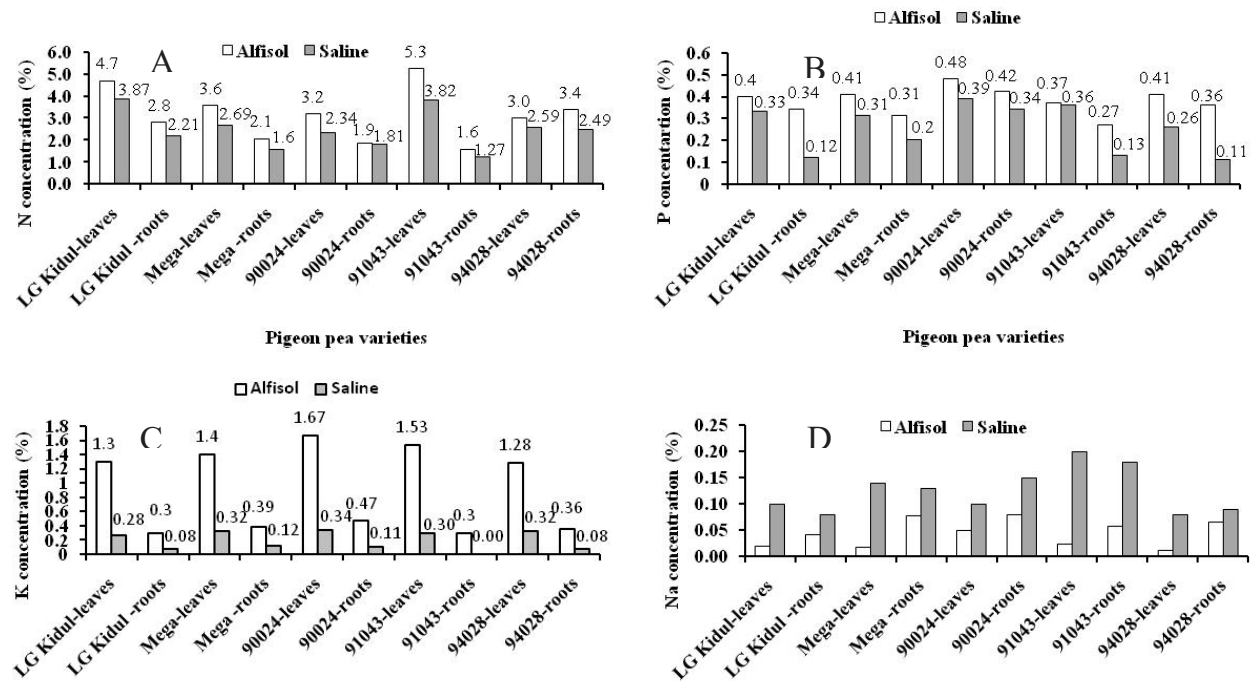

Pigeon pea

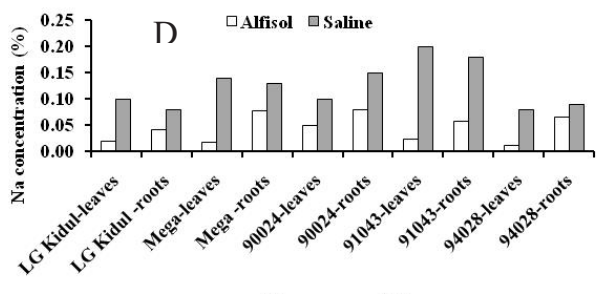

Pigeon pea varieties

Fig.1 The effect of salinity on the percentage of nutrient concentration in pigeon pea plant at 45 DAS: (A) nitrogen, (B) phosphor, (C) kalium and (D) sodium
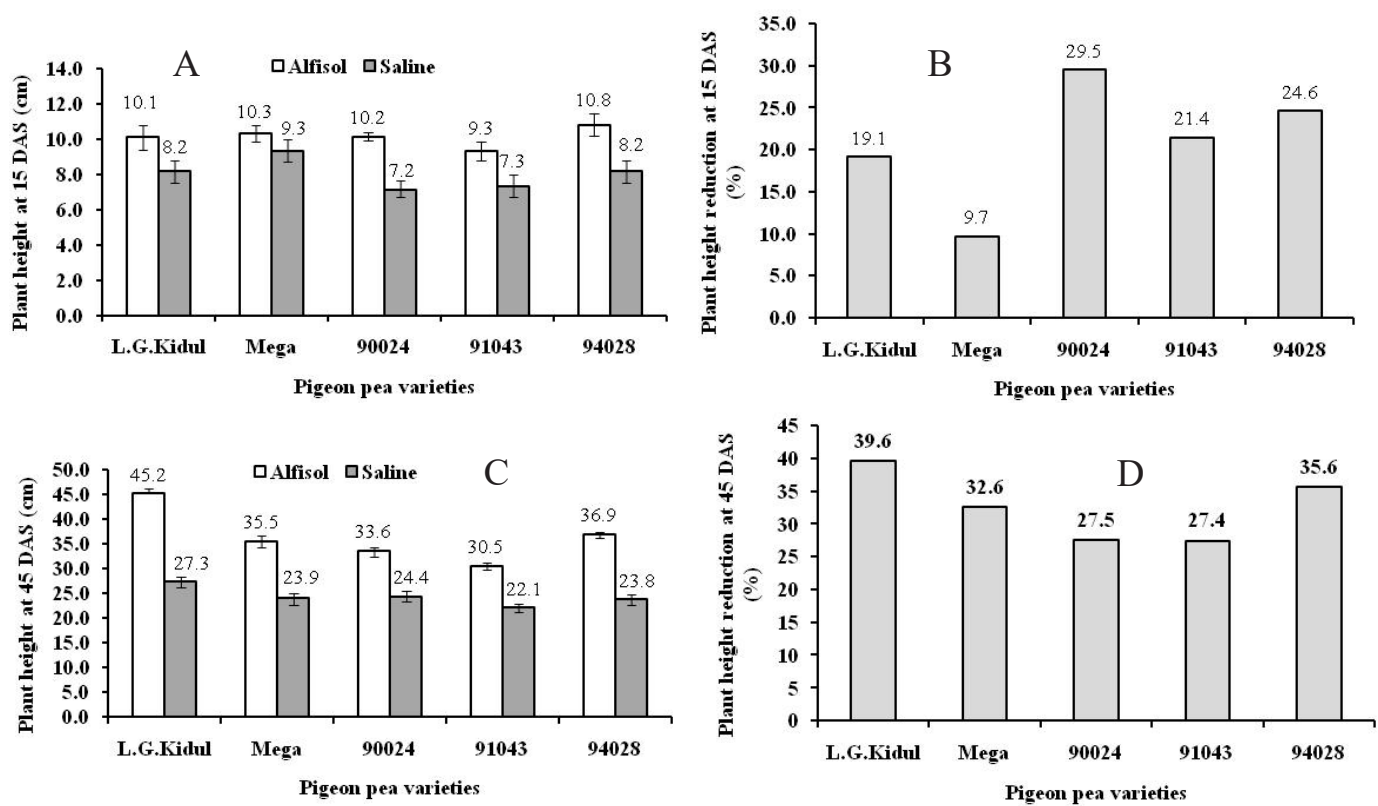

Fig. 2 The effect of salinity on plant height of pigeon pea at (A) 15 DAS and (C) 45 DAS; and the effect of salinity on plant height reduction of pigeon pea at (B) 15 DAS, and (D) 45 DAS

Figure 1 displayed the concentration of different nutrient in pigeon pea plant. The macro nutrients, e.g., N, P and K were relatively higher in the leaves and roots of pigeon pea grown 
on Alfisol soil than on saline soil (Figs. 1A, 1B and 1C). In contrary, Na concentration in leaves and roots of pigeon pea grown on Alfisol soil was lower than those of pigeon pea grown on saline soil (Fig. 1D). Higher concentration of N, P and K in pigeon pea grown on Alfisol soil indicates higher absorption of N, P and K from Alfisol soil. Higher sodium concentration in pigeon pea grown on saline soil suggests higher absorption of $\mathrm{Na}$ from saline soil. This finding was in line with other research results $[5,9]$. High concentration of Na was also found in porang [5] and cowpea [9] which were grown on saline soils.

\subsection{Effect of salinity on plant height}

Plant height at 15 DAS and 45 DAS as shown in figures 2A and 2C indicate lower growth rate of pigeon pea grown on saline soil than on Alfisol soil. A retardation effect of saline soil has started at the beginning growth stage, 15 DAS (Fig. 2 B). At a later stage (Fig. 2D), a retardation effect of saline soil was found to be worse (Figs. 2C and $2 \mathrm{D}$ ). The difference in growth retardation indicates the difference of pigeon pea varieties in responding to salinity (Figs. 2B and 2D). At a later stage, L.G. Kidul showed the most sensitive genotype based on the plant height character. The plant height of porang (A. muelleri Blume), known to be sensitive plant species to salinity, was also hampered on saline soil [5]. Similar research result that cowpea plant height was significantly reduced with an increase of salinity [9].

\subsection{Effect of salinity on shoot diameter}

The adverse effect of saline soil was also observed on shoot diameter at 45 DAS (Table 3A). The genotype of pigeon pea differently responded to salinity (Fig. 3B) similar to the observation on plant height. Thus, shoot diameter is also considered to be a good parameter to evaluate the response of pigeon pea to salinity. The shoot diameter of pigeon pea variety Mega was found to be the most adversely affected among other pigeon peas tested.
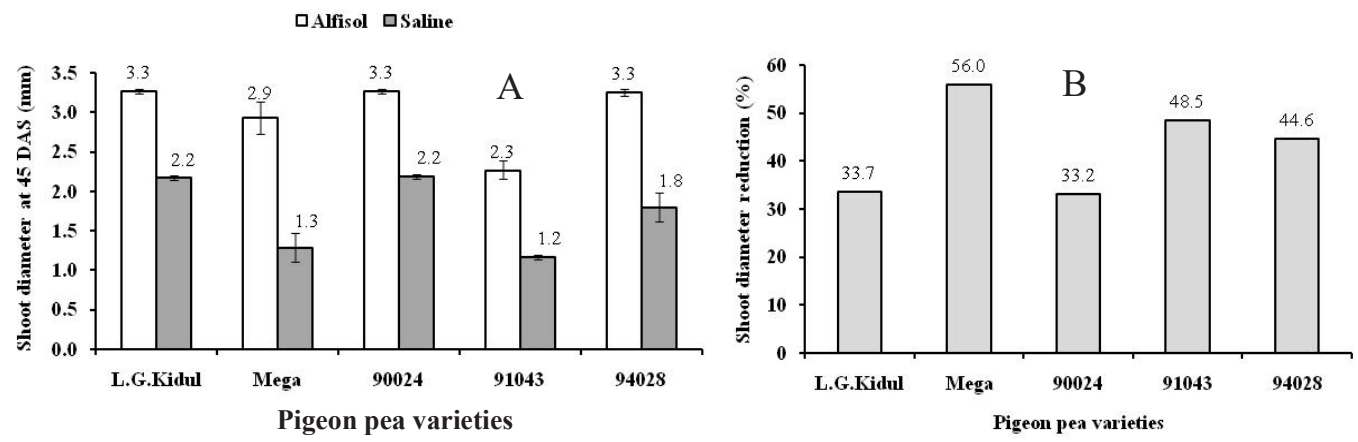

Fig. 3 (A) The effect of salinity on shoot diameter of pigeon pea at 45 DAS and (B) the effect of salinity on shoot diameter reduction

\subsection{Effect of salinity on root dry weight and root dry weight reduction}

Root growth of pigeon pea measured as root dry weight was significantly affected by the saline environment (Fig. 4A). Thus, root growth is also considered to be a good parameter for examining the pigeon pea to saline environment. The degree of retardation due to salinity varied among the genotypes tested (Figs. 4A and 4B). The root growth of pigeon pea variety L.G. Kidul was the most severely affected by salinity. Root growth of porang measured in term of dry weight of root was also retarded when grown on saline soil [5]. 

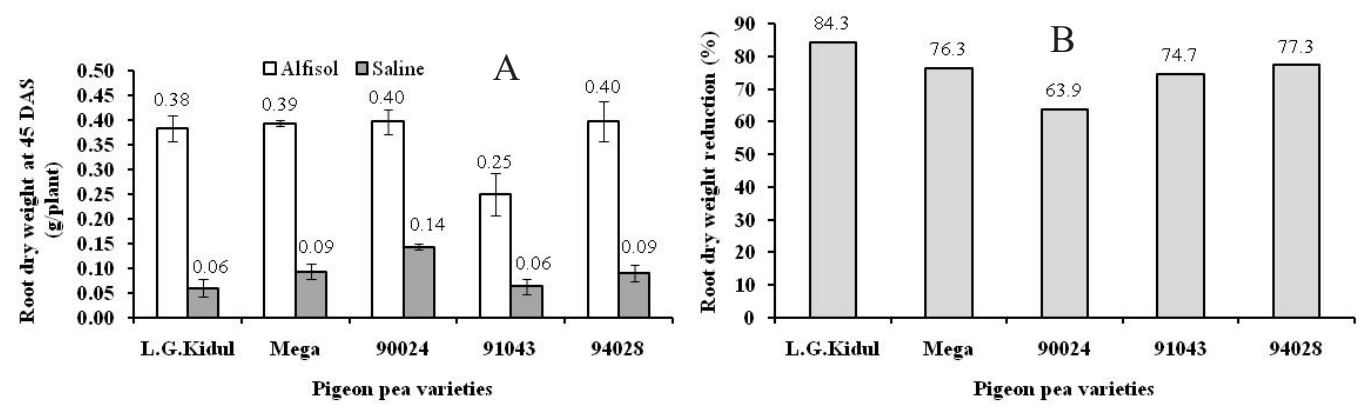

Fig. 4 (A) The effect of salinity on root dry weight at 45 DAS and (B) the effect of salinity on percentage of root dry weight reduction.

\subsection{Effect of salinity on shoot dry weight and shoot dry weight retardation}

The shoot dry weights of pigeon pea grown on Alfisol soil was significantly different to the shoot dry weights in saline soil (Fig. 5A). Pigeon pea grew better on Alfisol soil than on saline soil as indicated by higher shoot dry weight. Shoot dry weight reduction due to saline environment ranged from $62-77 \%$ (Fig. 5B). The most severe effect of salinity on growth was observed on pigeon pea genotype 94028 (Fig. 5B). The growth reduction of more than $50 \%$ suggests that pigeon pea is susceptible to saline environment. Therefore, it is important to identify other genetic resources of pigeon pea which are more tolerant to salinity to utilize potential saline soil in Indonesia.
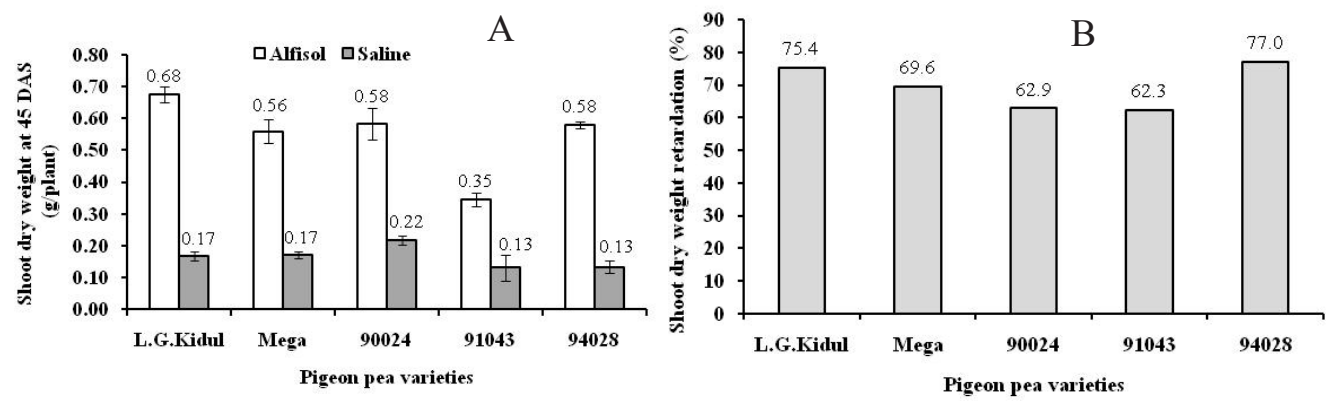

Fig. 5 Effect of salinity on shoot dry weight at 45 DAS (A) and percentage of root dry weight reduction $(\mathrm{B})$

Sodium is known to be toxic to some plants, like soybean, peanuts, cowpea and porang, resulting in lower growth and yield $[1,2,3,4,5,9]$. The growth of porang plants was severely reduced on saline soil and the reduction of plant growth was reported to be associated with higher concentration of $\mathrm{Na}$ in porang plants [5]. Pigeon pea contained higher concentration of sodium $(\mathrm{Na})$ on saline soil than on Alfisol soil which leads to growth retardation (Figs. 1D, 2A, 2C, 3A, 4A and 5A). Salinity caused reduction in chlorophyll content in plants [10]. Chlorophyll plays an important role in photosynthesis to produce photosynthate necessary for plant growth. Consequently, a reduction of chlorophyl due to salinity resulted in significant reduced plant growth and yield [10, 11, 12, 13, 14, 15]. 


\section{Conclusions}

All genotypes of pigeon pea grew better on Alfisol soil than on saline soil. The growth of pigeon pea measured in plant height, shoot diameter, root dry matter, shoot dry matter, was severely retarded on saline soil. The growth of pigeon pea on saline soil was specifically characterized by shorter plant, smaller shoot, less root mass, less shoot mass. The degree of susceptibility of pigeon pea varieties to salinity varied. In terms of shoot dry matter, pigeon pea genotype 94028 was found to be the most susceptible to salinity. In general, the growth of all genotypes of pigeon pea were retreated by salinity. Further research is needed to identify pigeon pea genotype which are more tolerant to salinity.

Acknowledgement. The Indonesian Legume and Tuber crops Research Institute (ILeTRI) granted the Funds for soil and plant analysis. The author is thankful to Mr. Abdullah Taufiq for meaningful discussion on salinity.

\section{References}

1. T. Sundari, A. Taufiq. Penampilan genotipe kedelai pada cekaman salinitas. Prosiding Seminar Hasil Penelitian Tanaman Aneka Kacang dan Umbi 2016

2. R.D. Purwaningrahayu, H. Kuntyastuti. Efektivitas amelioran dan toleransi genotipe kedelai terhadap salinitas pada tanah salin. Prosiding Seminar Hasil Penelitian Tanaman Aneka Kacang dan Umbi 2016

3. R.D. Purwaningrahayu, H. Kuntyastuti, T. Sebayang, Syekhfani, N. Aini. Bul. Palawija 14. (2016)

4. A.Taufiq A, A. Wijanarko, A. Kristiono. Bul. Palawija 14 (2016)

5. M. Soedarjo, Y. Baliadi, Djufry. J. Res. Studies in Agric. Sci. (IJRSAS) 6 (2020)]

6. S. S. Kurniawan, L. A. P. Putri, M. K. Bangun. J. Agroekoteknologi 1 (2013)

7. A. Maintang, P. Hanifa, R. Agustin. Potensi kacang gude sebagai komponen diversifikasi pangan. Prosiding Seminar Hasil Penelitian Tanaman Aneka Kacang dan Umbi 2014.

8. N.I nayah, A. Amir, Hendrayati. Daya terima masyarakat terhadap biskuit dengan: substitusi tepung kacang gude. Media Gizi Pangan, 26 (2019)

9. P.R. Patel, S. S. Kajal, V. R. Patel, V. J. Patel, S. M. Khristi. J. Plant Physiol. 22 (2010)

10. Y. Ali Y, Z. Aslam, M. Y. Ashraf, G. R. Tahir. J. of Environmental Science \& Technology 1 (2004)

11. D. Kotagiri, V. C. Kolluru. Biomedical \& Pharmacology J. 10 (2017)

12. S. Puvanithal, S. Mahendran. Sch. J. Agric. Vet Sci. 4 (2017)

13. I. Jahan, M. M. Hossain, M. R. Karim. Progressive Agric. 30 (2019)

14. N. Zahra, Z. A. Raza, S. Mahmood. Brazilian Archives of Biology and Technology 63:110.

15. A.S ogoni, M. O. Jimoh, L. Kambizi, C. P. Laubscher. 2021. Horticulturae 7 (2021) 